\title{
Compassion without action: Examining the young consumers consumption and attitude to sustainable consumption
}

\author{
Dr. Margee Hume* \\ Griffith Business School \\ Griffith University \\ Nathan Campus, 4111, Qld \\ Australia \\ m.hume@griffith.edu.au
}

\begin{abstract}
The concept of developing sustainable consumption practices has been a factor for discussion within academic literature for nearly half a decade. Many have argued the consequences of unmonitored consumption practices within a 'throw-away' society would lead to environmental, social and economic degeneration. With consumption no longer hindered by global boundaries, there is an emergence of a common class of people within society consuming in vast amounts, over great distances from one another, and reaps irreparable environmental damage. The onus of developing sustainable practice is no longer the sole responsibility of economies of affluence and specific segments of our economy but has become the responsibility of all stakeholders. Using a triangulated qualitative approach, the aim of this research is to advance our understanding and definition of sustainability in the key stakeholder group: the young consumers, Y generation. The research will focus on understanding their consumption footprints and their view of the notion of sustainability. Implications for social changes, policy and practice will also be presented.
\end{abstract}

Key words: Sustainability, Y generation, young consumers, economic sustainability, environmental sustainability, consumption footprints.

*I would like to acknowledge the support of research assistants Celeste Alcaraz and Melissa McLennan and funding from SIRC, Griffith University. 


\section{Introduction}

The concept of developing sustainable consumption practices has been the focus of discussion in the academic literature for nearly half a decade (Robins, 1999). Vance Packard (1960) argued the consequences of unmonitored consumption practices within a 'throw-away' society would lead to environmental, social and economic degeneration. Barnet and Cavanagh (1994) state consumption is no longer hindered by global boundaries due to the emergence of a common class. This class consumes in vast amounts, over great distances from one another and reaps irreparable environmental damage (Robins, 1999). The onus of developing sustainable practice is no longer the sole responsibility of economies of affluence and specific segments of our economy (Robins, 1999; Longhurst, 2006). Rather, it has become a responsibility of all stakeholders including and not limited to industry, government and community sectors including customers. This paper will advance understanding, definition and approaches to sustainability in the key stakeholder group; the young consumers Y generation (Ergi \& Ralston, 2004) (those born between 1978-1994).

Sustainability is a word with over three hundred definitions (Manderson, 2006). With a lack of consensus on a clear definition, a clear set of the terms of reference, a clear understanding of the variables that influence sustainable living, this topic warrants attention in the future research agenda. The lack of a fundamental clear definition of sustainability impedes strategies that change attitudes and behaviors and develop sustainable policy and practice. This inadequate understanding and clarity of "what is sustainability" obstructs the communication of sustainability to internal and external stakeholders. With many organizations hampered by the limited understanding and ambiguous conceptualities of sustainable consumption, it is essential 
we develop a patent comprehension of what is sustainability and what stakeholders are doing to practice it. The aim of this research is to advance our understanding and definition of sustainability, in a particular stakeholder group, the $\mathrm{Y}$ generation cohort of the consumer stakeholder group.

Although a wide variety of stakeholders, such as, not-for-profits, non-governmental organisations, private sector organisations, specialist organisations and consumers, have been identified within the literature, little knowledge pertains to perceptions, attitudes and beliefs of sustainability and its facets (Daub and Ergenzinger, 2005). A key stakeholder valued in the conceptualization of sustainable living and practice is the young consumer (Bentley, Fien and Neil, 2004). Young consumers represent the future of our society (Heaney, 2006; Smola and Sutton, 2002). They are the future consumers, the future workers and the future innovators (McCrindle, 2007). Their role as the leaders and decision makers of the future, positions them as ideal candidates to enlighten us of the issues related to developing sustainable strategies. Examination of this generational segment will allow a more sophisticated understanding of "young people" and the issues needed for the future i.e. sustainability. Marketing practice researcher McCrindle (2007) has recognized the strong consumer value of this Y gen group, but suggests that their social awareness has not translated into compassionate practice (McCrindle, 2007). Others have researched young people's consumption and how they can make changes in their own consumption. They are catalysts for change when considering sustainable consumption (Bentley, Fien and Neil, 2004). This research, however, has not specifically looked to define their perception of sustainability and the elements they suggest influence sustainability. Websites such as Popzine (2004) and interfacesustainability.com (2008) are reporting the 
importance of living in harmony with the planet and creating sustainable living practices. It is suggested that change strategies need to focus on making sustainable life styles cool and fashionable, communicating the personal benefit of sustainable living to the young consumer. In some countries, it is suggested 1 in 3 consumer dollars are spent by the young consumer (Ginsberg, 2004). This group not only becomes essential to understanding sustainable practice but also in creating much needed demand for sustainable changes.

It is suggested that social enlightenment of this busy, career focused, materialistic group is questionable (McCrindle, 2007). With limited academic research, this view is subjective, but warranting of further exploration. By developing an understanding of the consumption footprints and perspectives of the social conscience of this group, companies can develop sustainable marketing strategies targeting this popular segment. It is essential for firms and consumers to realize there is a direct correlation between life quality and social economic and environmental and responsible consumption patterns (Robins, 1999; Placet, Anderson and Fowler, 2005; Marrewijik and Were, 2003; Kilbourne, McDonagh and Prothero, 1997). Quality of life not just related to material possessions.

The practice of excessive consumption is a key contributor to being un-environmental, unsustainable, and causing social detriment. Consumption patterns in modern society and particularly, in the young consumer Y gen cohort, have changed and continue to change rapidly due the breakdown of geographic boundaries and larger proportions of higher disposable incomes (Csikszentmihalyi, 2000). Y gen consumers are purchasing more, demanding more and living on a higher debt to equity ratio (Abela, 2006) than their parents. Researchers suggest marketing as a major contributing factor to societal degeneration and excessive consumption in 
this group. Marketing has been suggested to encourage hedonistic behavior (O'Shaugnessy and O'Shaunessy, 2002). The more we consume the higher the firm's objective for market share, the greater the marketing approach. Moreover, the more marketing, the more awareness and interest created, increasing consumer consumption and profitability for firms. With the economic and social motivation in the $21^{\text {st }}$ century on developing and providing a sustainable world (Daub and Ergenzinger, 2005) excessive consumerism, marketing and business practices and the consumer behaviour of the young consumer, (O’Shaughnessy and O'Shaughnessy, 2002) must be explored to nurture social change that assists in the construction of a sustainable world.

\section{Defining Sustainability}

In an attempt to advance sustainability, past definitions of sustainable practice have focused on strategies that address environmental or ecological concerns. Many organisations have attempted to address sustainability through small internal cultural changes or development of 'greener' products (McCarthy, 2007) and greener practices. Many efforts have been slowed and hampered due to a lack of interest of employees and/or consumer awareness. By recognizing that the green environment is not the only bionetwork affected by consumerism and excessive marketing practice and that sustainability should include other social and economic networks (Christensen, Godskesen, Gram-Hassen, Quitzau and Ropke, 2007), a better understanding of sustainable practice can be gained. By steering marketing practice towards considering broader environments and environmental definitions (Connolly and Prothero, 2003), a comprehensive approach to sustainable marketing and sustainable living can be achieved. Daub and Ergenezinger (2005) suggest three dimensions requiring consideration in the development and implementation of a sustainable form of business management (Daub and Ergenzinger, 2005). 
These include economic, social and ecological. The 'firm' must seek to move beyond traditional marketing practices and engage in society marketing to educate stakeholders about sustainability within the marketplace (Daub and Ergenzninger, 2005).

Almost considered a 'fad', company's practices to achieve sustainability are often reactive, with strategies developed for short-term success or targeted towards a niche segment of the marketplace (Dolan, 2002). The perception of limited profitability from these efforts has hindered growth of the sustainability effort, with companies and consumers perceiving going green and the cost of communicating the green message to the mainstream market as a green provider too expensive and too difficult (Mader, 2008; Wirtenberg, Lipsky, Abrams, Conway and Slepian, 2007). In addition, there has been little evidence to suggest success of these endeavors (Daub and Ergenzinger, 2005; Wirtenberg et al, 2007). In particular, the success of acceptance and adoption by the firm's targeted consumer. It is proposed that companies can increase brand equity and reputation from potential consumers by undertaking sustainable marketing practice which account for social, economic and ecological dimensions (Dolan, 2002). Furthermore, the issue of corporate social responsibility, stakeholder responsibility and marketing practice to influence sustainability are in the early stages of discussion and interest is growing. Addressing sustainability is a multi-faceted approach. There is little cohesive research pertaining to the definition of sustainability, with research into the triage of factors rudimentary. Sustainability is largely viewed as a one-dimensional problem rather than a three dimensional problem which has slowed sustainability research. This research will investigate and advance these deficiencies by exploring the opinions of the $\mathrm{Y}$ generation with respect to consumption and sustainable practice including economic, social, community and family, technological, 
environmental, general business and marketing practice issues, and the future, in order to identify the multiple dimensions of sustainability.

\section{Consumerism}

One of the main causes of environmental and social detriments is consumerism. Consumerism is a term used to describe the effects of gathering and purchasing material possessions to increase happiness and social position (Borgmann, 2000; Csikszentmihalyi, 2000; Kasser and Ahuvia, 2002; O'Shaughnessy and O'Shaughnessy, 2002). Recent research has suggested that the excessive consumption of society negatively and detrimentally affects the sustainable living of communities (Belk 1985, 1988). There is some evidence of those opting for a simple lifestyle, rejecting the excesses of the modern consumer economy and positively engaging in sustainable living (Belk, 1985; Borgmann, 2000; Csikszentmihalyi, 2000; Kasser and Ahuvia, 2002; O'Shaughnessy and O'Shaughnessy, 2002; Wright and Larsen, 1993; Zinkhan, 1994; Zinkhan and Prenshaw, 1994); yet these case studies appear limited. Furthermore, current research and practice by the anti-consumerist lobby is actively pursuing public policy and legislation that restrains the activities that marketers can engage in to target consumers, innovate new services and products, and use excessive packaging and more (O'Shaughnessy and O'Shaughnessy, 2002). These groups favor encouraging ethical practice and the adoption of a responsible corporate and social approach to marketing practice (Mujtaba and Jue, 2005; Borgmann, 2000, Csikszentmihalyi, 2000; Kasser and Ahuvia, 2002). Critics of consumerism argue that materialism and strong affiliations with status enhancing brands (O'Guinn and Shrum, 1997; Schmuck, Kasser and Ryan 2000; Zinkhan and Prenshaw, 1994) and consumer cultures has an adverse effect on the social value of society and community. This suggests a relationship 
between excessive consumption and sustainable community development (Zinkhan and Prenshaw; 1994; O'Shaughnessy and O'Shaughnessy 2002; Wright and Larsen 1993).

Conversely, economic consumerists place much emphasis on consumption and suggest that innovative development and high standards of living would not develop without the economic impacts created by increased consumption and marketing (Firat and Venkatesh, 1995). Moreover, economic consumerists suggest that consumers' freedom of choice should dictate what is consumed, how much is consumed and the structure of the consumer society (Firat and Venkatesh, 1995; Mujtaba and Jue, 2005). This research supports the view that any framework developed to explore sustainability should focus directly on the consumer. Other researchers suggest that consumption as such is not the problem. The problem is the life balances and 'work to spend culture' and environmental damage that comes with over-consumption that affects society and is influencing the lack of sustainable living in our societies. They suggest that strategies to reduce this problem and prevent this imbalance will assist in creating sustainable consumption (Sanne, 2002). Whatever the belief (Belk and Pollay, 1985; Borgmann, 2000; Twitchell, 2002) the debate is ongoing as to how marketing practice influences consumption and whether it enhances or diminishes consumer welfare and influences sustainability (O'Shaughnessy and O'Shaughnessy, 2002). To comprehensively advance the conception of sustainability and sustainable strategies we need to indentify the factors and issues that are perceived to be related to sustainability, sustainable innovation and sustainable marketing practice. By exploring the Y generational segment (Heaney, 2006), this paper aims to advance our understanding of these issues. 


\section{Generational framework for young consumers}

Generation marketing is founded on research that links changes in values, motivations, preferences and attitudes to different eras (Inglehart, 1997; Mitchell, 1998). The changes in consumption expenditure, life experience, technological developments, environmental issues and regulatory frameworks are argued to have a potentially significant impact on young people that can best be understood by taking a generation approach. Generational determined lifestyles and social values exercise as much influence on buying and purchasing as more commonly understood demographic factors like income, education, and gender do, perhaps even more (Schewe and Meredith, 2004; Wellner, 2000; Lake, 2006).

Different generations and demographic consumer groups are exposed to: a) different social and economic opportunities and barriers, b) different types of technology activities, c) different social perceptions and different community norms, and d) different life experiences and events (Heaney, 2006). The $\mathrm{Y}$ gen is known for wealth generation, excessive big ticket spenders, conspicuous consumption, fashionistas, quick fixes and career advancement, all characterized by excesses (Hoey, 2008). This group is seen as popular to marketers as excessive consumption is suggested as both the antecedent and the consequence of the success of current marketing and business practice by firms (Csikszentmihalyi, 2000; O'Shaugnessy and O'Shaugnessy, 2002; Hansen and Schrader, 1997). The Generation Y are the parents of tomorrows children. They are currently in tertiary education or early working life, are technology efficacious, have been exposed to capitalist rule, the rise of China, high technology, globalization and the opening of trade barriers, and are the "cool consumers" of products with "image" (Heaney, 2006). They are conscious socially, culturally and environmentally; purposeful in 
nature; confidant; require individual experiences and demand rationale due to a more skeptical nature than previous generations (Sheahan, 2005; Sullivan and Heitmeyer, 2008). Self-interest is a driving characteristic of this cohort; the $\mathrm{Y}$ Generation seeking authentic efforts from organisations to capture attention (Sheahan, 2005). Also, considered innovative and creative due to traits of informality and lack of respect for traditional procedures and practices, this generation are more likely to engage in processes which stimulate their internal motivating desires (Sullivan and Heitmeyer, 2008; Sheahan, 2005; Heaney, 2006). Generation Y are considered the most consumption orientated generation of all time due to the abundance and availability of products and services (Sullivan and Heitmeyer, 2008).

A generational approach is aimed at facilitating the development of sustainable living, consumption and marketing practices for consumers using generation marketing (Morton, 2003; Paul, 2001). Sustainable consumption would mean consumption that balances time and monetary expenditure, while satisfying basic needs of life and the future needs of generations (Robins and Roberts, 1998). Sustainable consumption is closely aligned to quality of life and consumer well being issues (Cornwell and Drennan, 2004). The main aim of this project is to investigate this young consumer group to find meaning of sustainability and sustainable practice and identify the issues and attitudes interrelated to sustainable practice and policy. This study will be significant and innovative in its use of a generation's framework (Strauss and Howe, 1991) in researching young consumer's definitions and attitudes consistent with creating a sustainable future (Harwood, 2002; Morton, 2003; Norum, 2003). We are not aware of any previous research using this approach. A triangulated qualitative methodology is adopted, based on the intention of the study, and the exploratory nature of this study. 


\section{Data and Method}

The purpose of this study is to use qualitative methods to model the dimensions of sustainable innovation and marketing practices in young consumers ( $\mathrm{Y}$ gen) using a multi-perspective (ecological, economic and social) approach. The current literature informs the conceptual map. The conceptual map was used to develop and support the focus group and interview questions. This research has generated themes from explanations and definitions offered in the literature and examine how the themes fit the data collected from each of the consumer interviews. The emergent themes are offered based on their data fit. Hyde (2000) and others (Holloway, 1997; Mantzoukas, 2004) support using this practice in qualitative work as a practice for theory generation.

This research uses a three-study approach to evaluate the perspectives of sustainability and the actual practice in the $\mathrm{Y}$ gen segment. First, the perspective of sustainability was extracted from a combination of two focus groups (each with 8 persons). Second, the focus groups were informed of the interview questions and in-depth interviews (22 interviews in total) were conducted, gathered and advanced discussion on each of the sustainability perspectives. Third, a set of footprint (analysis) surveys were conducted on 60 screened Y gen candidates. As this project is an exploratory study, a defined generalized group of people who met all eligibility criteria for full-scale research study were identified by the use of screening questions (Holloway, 1997). These customers functioned as lead users (von Hippel, 1986) in this context and were found to be representative of this sample group. With careful sampling and equally careful collection techniques, a surprisingly small number of interviews, narratives or focus groups can 
yield the data to answer your research question (Holloway, 1997). The general rule in qualitative research is that you continue to sample until you are not getting any new information or are no longer gaining new insights. This is referred to as theoretical saturation. Moreover, theoretical saturation is a process whereby themes and constructs from one case or interview are substantiated by the evidence of another case (Eisenhardt, 1989). Theoretical saturation was deemed to be achieved at 22 candidates. Moreover, consistent with the suggested valid range of case sampling of more than ten cases (Eisenhardt, 1989); the 22 consultant interviews conducted were found to be satisfactory for valid sampling. With the main aim of this research to investigate, define and identify factors that contribute to the development of sustainability, sustainable living, innovation and marketing practice, opened ended interviews were conducted. The specific question topics of what is sustainability, what are the economic, environmental, social, family and community, technological and general business and marketing practice were used. A final question asking generally about where we will be in the next 25 years was also included. Findings of these interviews can be found in Table 1, specifically reporting the definition of sustainability and strategies for the 25 years, with Table 2, reporting the issues related to economic issues; people community and social issues; technological issues; environmental and ecological issues.

A set of scripts were obtained from each of the candidates. Consistent with the method outlined by Hubbert, Sehorn and Brown (1995), the unit of analysis was the script. The scripts from both the focus groups and the interviews were transcribed. These transcripts included the definitions and the meaning and expectations of "what is sustainability and the economic, technological, social, people and community, environmental and ecological, and general business 
and marketing practice issues that were important to the generation $\mathrm{Y}$ (young consumer). The scripts were coded separately, with each issue recorded for each individual and then combined recording frequency of responses. These were organized using a conceptual map (Miles and Huberman, 1994) and analyzed based on understanding of the extant literature and frequency of the response. This technique was derived from previous research and is consistent with Arnould and Price (1993).

Actual practice was determined using a modified version of the ecological footprint questionnaire based on content offered in current research (Kitzes, Peller, Goldfinger and Wackernagel, 2007; Wackernagel and Rees, 1996; Rees, 1992). Ecological footprint compares human demand on nature with the biosphere's ability to regenerate resources and provide services (Rees, 1992). It does this by assessing the biologically productive land and marine area required to produce the resources a population consumes and absorb the corresponding waste, using prevailing technology. This metric looks at the consumption of energy, biomass (food, fiber), building material, water and other resources which are converted into a normalized measure of land area called 'global hectares' ( $g h a)$. Ecological foot printing is now widely used as an indicator of environmental sustainability (Rees, 1992). Other researches have used these techniques for assessment of emissions and ecological impact from product consumption (Browne, O'Reagan and Moles, 2008). A group of candidates, who met all eligibility criteria for full-scale research study, were identified by the use of screening questions and were asked to complete a simple questionnaire based on their actual practice in daily lives using the items and topic areas of the footprint questionnaire. These scripts were then collated and frequency of recordings was collated. Sixty (60) semi-structured footprints questionnaires in total were 
conducted in a face-to-face interaction with candidates. Face to face implementation of the survey allowed for clarification and further probing. The frequencies of responses and comments are presented in Table 3.

The research adopts a pragmatic interpretive approach that aims to provide an understanding of the issues leading to explanation (Denzin and Lincoln, 2000; Crotty, 1998). The use of theory building (Neumann, 2003) will identify and validate the number of factors that will advance sustainable business and sustainable practice, from a purely 'green' environmental approach to incorporate other topics including economic, environment, family, social, economic, technological, general business and marketing practice environments. The rationale for using a qualitative approach was to ensure the extraction of thick descriptions related to the phenomenon of sustainability and the emphasis on the triage of factors; economic, social and ecological. The qualitative approach allowed for open discussion with candidates and clarification of responses.

\section{Findings}

The data in Table 1 illustrates the meanings that the respondents assigned to the term sustainability and the issues they felt were important. Several interesting issued emerged. First, the definition of sustainability is ethnocentric with very few consumers identifying global issues and strategies. Most definitions related to local communities and supported strategies for local environments and communities. There appeared to be a strong focus on the environment and recycling with accountability for waste, damage and environmental balance as key factors. Sustainable innovation focused on the creation of new products and services without harming other services, business and environments and minimizing reinventing similar products merely 
for competition. Table 1 data also offers insight into what consumers suggest as important issues for the next 25 years and how they felt they could or would improve strategy for the development of sustainable living. The key areas highlighted included Corporate Social responsibility (CSR), political agendas focused on sustainability, developing mind shifts in consumer thinking about sustainability and creating sustainable education including courses and programs that create jobs, focus on areas of community need and consider future environments and needs.

Insert Table 1 here

The data in Table 2 offers the issues respondents related to the economic issues, social and people issues, environmental and ecological issues and general business practice and marketing issues. Interestingly, the key economic factors offered related to income disparity and wealth distribution, inflation and interest rates and how they affect the consumer's ability to buy affordable housing and the standard of living. Loan practices and the development of sustainable corporate investment also featured in the economic issues required for sustainability. Social issues focused heavily on the care of the vulnerable and the aged, the development of communities and villages, discouraging excessive consumption; crime and education. Each of these being the focus for creating sustainable future living. Environmental factors focused on the depletion of the earth's resources, climate change, animal extinction, both corporate and individual waste, renewable energy and recycling are the main issues. Preservation of natural spaces, taxation on emissions and corporate social responsibility were also included yet not as frequent.

Insert Table 2 here 
Interestingly, marketing and business practice focused on energy efficiency and environmental policies as the most important areas, with the use of the Internet, responsible innovation, support of agribusiness, profit sustainability tradeoffs, environmental audits, tax incentives, shame files and the development of environmentally safe distribution channels all emphasized as important. It was evident this group took a proactive approach to marketing strategies and focused on what business could do to improve the situation rather than adopt a blame approach for past sins of firms and the role of marketers and business in creating consumerism and materialism.

The final tabulation of findings was the results of the footprint questionnaire. Table 3 reports the extremes of behavior offering a snapshot of the actual practice of the young consumer. Some candidates did suggest that depending on time and financial circumstances, they may adopt more environmentally friendly practices. These would be an exception to their behavior. It was evident that the practice of this group was far from their compassionate beliefs about how to create sustainability and the creation of sustainable consumption. Results indicated that only one candidate out of 60 practices waste recycling, 6 candidates practice environmentally friendly transportation, using cycling and walking as the preferred method of transportation, with all candidates using or proposing to use aircraft more that once a year for holidaying and general transportation. The majority of candidates had no water saving devices apart from (3) that had home water tanks. No person grew their own food or vegetables, lent or borrowed uncommon items and recycled technology. All candidates owned more than four pieces of technology, updated them regularly for better models and threw away the older versions when superseded. There was a large number of candidates living in large homes however most lived in share housing, units and average size houses. Many candidates (37) lived in large housing with only one other co-habitant. 
Insert Table 3 here

The footprint data gathered revealed some very interesting behaviors. It is evident that the humanistic approach to defining sustainability was not evident in practice. It was evident that this highly technologically efficacious group did not practice any recycling, renewable energies consumption and produce production. An important practice was to update technology for the latest models with little thought to the disposal of the older units. Conservative transport practices do not appear evident, with flying seen as an essential and necessary annual activity. Is the disparity between the altruistic compassionate values toward defining and understanding sustainable living and their footprint practicing hypocrisy or a failure to convert knowledge into practice or purely a lack of action? Alternatively, are the definitions offered on the meaning and needs for sustainability merely a regurgitation of the hype of green marketing and sustainability propaganda? Is there still hope for change and implementation of sustainable practice is this group? In addition, what can we do to educate them into change?

\section{Contribution to theory and practice}

Interestingly, this research supports the early exploratory work of other researchers. Shaw, Newholm and Dickinson (2006) established there was tension between consumer power and choice and sustainable choice living. Albeit this study was small and not identically focused, early evidence supports the findings of paradox between thought and action. This research further cements the findings of Tanner and Kast (2003) who suggested that green purchases were not significantly linked to moral thinking and socio economic characteristics of consumers. Green purchases were found to be related positively to attitude to local producers and negatively associated to time inconveniences. It is evident from this work, that there is a strong moral 
stance on sustainability and support for sustainable practice, with practice considerably limited. This finding is of importance and suggests that other dimensions outside the bounds of principles and ideals drive actual social action. There is no doubt that further research into the identification of the drivers of sustainable practice in all generations, especially the $\mathrm{Y}$ gen, advancing Tanner and Kast (2003) is warranted and would be of value.

\section{Implications for Future research}

No doubt, this group reflects the generational attitudes they have developed over time. Modern technologies, life luxuries, booming economies, open trade and travel barriers are all generational factors of this sample. These influences certainly affect the practice and understanding of sustainability. Future research would be encouraged in other generational segments, such as the $\mathrm{X}$ generation and the baby boomers, to ascertain if the disparity between understanding and practice is evident. The study is limited by the different sample groups used to extract meanings and to ascertain practice, however this was preferred so not to bias the group and gain a clearer reflection of real footprint practice. Future research would be well suited for a large empirical survey ranking and rating consumer perceptions to the aspects identified by this group. Moreover, large-scale examination of consumption using the modified footprint questionnaire would also further advance this area of research.

\section{Managerial Relevance}

It is evident that there is some understanding of the requirements of sustainability and that the implementation or ease of implementation is the issue for the $\mathrm{Y}$ generation. This cohort, albeit educated and considered environmentally aware, was highlighted not to engage in sustainable 
requirements. This group shows a compassionate humanistic understanding of what is required to create sustainability yet focuses these only on local and parochial issues. The Y Generation are ego driven in nature and expect attempts from organizations to encourage sustainable practice to be genuine and aligned with self interests. The research has highlighted the direct conflict between the consumption patterns of the Y Generation and compassionate sustainability values. In order to overcome this, programs and policies must demonstrate the ease at which one can reduce their ecological footprint and practice sustainable living. Change agents need to capture this group's behaviors by identifying their triggers to resisting change. The strategies and social change impetus must show how easy, fashionable and "cool" it is to create a sustainable world. In order for sustainability to improve, rather than merely quality of life, a global outlook needs to be adopted. Focus of sustainable change strategies should be aimed on Generation $\mathrm{Y}$ as a desired audience. Messages disseminated to capture Generation Y's attention must appeal to their self-interests and idealism and dispersed in areas where they congregate. Social change campaigns need to include incentive and understanding of the needs for the future and how the impact of poor practices and excessive consumption will damage the world and its people. This group needs to be informed that their contribution to sustainable practice is required, with sustainable practice designed and articulated as simply and conveniently as

possible. This group will not seek out change if it is not cost effective, convenient and selfserving. For their compassionate ideals to be constructed into practice and action this group need to be nurtured and convinced of the changes without their requiring of too much effort.

\section{Conclusion}

The primary aim of this paper was to examine the factors involved in defining and identifying the notion of sustainability, sustainable living, innovation and marketing practice. To enable 
further understanding regarding the intricate features involved within the sustainability debate, a generational approach was undertaken. Thus, the second aim of this paper was to further understand the notion of sustainability amongst the most consumption orientated generation of all time, Generation Y. Although these groups of consumers are considered socially, economically and environmentally conscious, a clear pattern of contradiction exists between what they know and what they practice in regards to sustainability efforts. Such findings has led to the suggestion for the need for marketing innovations and practices to take a societal stance and focus on the self interested nature of this cohort. The findings from this study also suggest other generational cohorts should be considered for further analysis to allow conveyance of a clear message regarding the impact of unsustainable practices and detriments on society. 


\section{References}

Abela, A.V. (2006). Marketing and Consumerism. European Journal of Marketing, 40(1/2): 516.

Arnould, E.J., \& Price, L.L. (1993). River Magic: Extraordinary Experience and the Extended Service Encounter. Journal of Consumer Research, 20(1): 24-45.

Barnet, R., \& Cavanagh, J. (1994). Global Dreams. Simon \& Schuster: New York in Robins, N. (1999) Making sustainability bite: transforming global consumption patterns. The Journal of Sustainable Product Design. (online)(6 February 2007) Retrieved March 23, 2008 from: http://www.bo.cnr.it/www-sciresp/OLD/Bacheca_OLD/pdf00000.pdf\#page=7.

Belk, R.W. (1985). Materialism: Trait Aspects of Living in the Material World. Journal of Consumer Research, 12(3): 265-280.

Belk, R.W. (1988). Possessions and the Extended Self. Journal of Consumer Research, 15(2): 139-168.

Belk, R.W., \& Pollay, R.W. (1985). Image of Ourselves: The Good Life in Twentieth Century Advertising. Journal of Consumer Research, 11: 887-897.

Bentley, M., Fien, J., \& Neil, C. (2004). Sustainable consumption: Young Australians as agents of change. Canberra, Australia: National Youth Affairs Research Scheme: 1-156.

Borgmann, A. (2000). The Moral Complexion of Consumption. Journal of Consumer Research, 26(4): 418-422. 
Browne, D., O'Regan, B., \& Moles, R. (2008). Use of embodied energy and ecological footprinting to assess the global environmental impact of consumption in an Irish city-region. Journal of Environmental Planning and Management, Abingdon: May 51,(3): 447.

Christensen, T.H., Godskesen, M., Gram-Hassen, K., Quitzau, M., \& Ropke, I. (2007). Greening the Danes? Experience with consumption and environment policies. Journal of Consumer Policy, 30: 91-116.

Connolly, J., \& Prothero, A. (2003). Sustainable consumption: Consumption, consumers and the commodity discourse. Consumption, Markets and Culture, 17: 275-291.

Cornwell, B., \& Drennan, J. (2004). Cross-cultural Consumer Consumption Research: Dealing with Issues Emerging from Globalization and Fragmentation. Journal of Macromarketing, 24(2): 108-121.

Crotty, M. (1998). The Foundations of Social Research-Meaning and Perspective in the Research Process, Australia: Allen \& Unwin Pty Ltd.

Csikszentmihalyi, M. (2000). Reflections and Reviews: The Cost and Benefits of Consuming. Journal of Consumer Research, 27(2): 267-272.

Daub, C., \& Ergenzinger, R. (2005). Enabling sustainable management through a new multidisciplinary concept of customer satisfaction. European Journal of Marketing, 39(9/10): 9981217.

Denzin, N.K., \& Lincoln, Y.S. (2000). Handbook of Qualitative Research (2 ${ }^{\text {nd }}$ ed), USA: Sage Publications.

Dolan, P. (2002). The Sustainability of 'Sustainable Consumption'. Journal of Macromarketing, 22: 170-181. 
Eisenhardt, K. (1989). Building Theory From Case Study Research. Academy of Management Review, 14(4): 592-611.

Ergi, C.P., \& Ralston, D.A. (2004). Generation cohorts and personal values: A comparison of China and the United States. Organizational Science, 15(2): 210-220.

Firat, A.F., \& Venkatesh, A. (1995). Liberatory Postmodernism and the Reenchantment of Consumption. Journal of Consumer Research, 22(3): 239-267.

Ginsberg, B. (2004) Purchasing for Sustainability: Young Consumers in the Green Marketplace: Why Youth? Why You? Retrieved $10^{\text {th }}$ October 2008, from http://www.popsustainability.org/popzine/issue3/trends3.htm.

Hansen, U., \& Schrader, U. (1997). A Modern Model of Consumption for a Sustainable Society. Journal of Consumer Policy, 20(4): 443-468.

Harwood, M. (2002). Talking to the generations: How to market to different age groups. Community Banker, 11(7): 28-33.

Heaney, J. (2006). Generations X and Y's internet banking usage in Australia. Journal of Financial Services Marketing, 11(3): 196-210.

Hoey, T. (2008). How to turn generation Y into generation \$. Sydney Morning Herald. $15^{\text {th }}$ March Retrieved $22^{\text {nd }}$ October 2008, from, http://www.smh.com.au/articles/2008/03/15/1205472147009.html

Holloway, I. (1997). Basic Concepts for Qualitative Research. Blackwell Publishing, Hubbert, A.R., Sehorn, A.G., \& Brown, S. (1995). Service expectations: The consumer versus the provider. International Journal of Service Industry Management, 6(1): 6 - 21. 
Hyde, K.F. (2000). Recognising deductive processes in qualitative research Qualitative Market Research. An International Journal, 3 (2): 82-90.

Inglehart, R. (1997). Modernization and postmodernization: Cultural, economic, and political change in 43 societies, Princeton, New Jersey: Princeton University Press.

Kasser, T., \& Ahuvia, A. (2002). Materialistic Values and Well Being in Business Students. European Journal of Social Psychology, 32(1): 137-146.

Kilbourne, W., McDonagh, P., \& Prothero, A. (1997). Sustainable Consumption and the Quality of Life: A Macromarketing Challenge to the Dominant Social Paradigm. Journal of Macromarketing, 17(4): 4-24.

Kitzes, J., Peller, A., Goldfinger, S., \& Wackernagel, M. (2007). Current Methods for Calculating National Ecological Footprints Accounts. Science for Environment and Sustainable Society, 4 (1).

Lake, L. (2006). The power of generation marketing. (online) (10 January 2007) Retrieved: 20 April, 2008, from http://marketing.about.com/od/demographics/a/generationmktg.htm.

Longhurst, M. (2006). Mediating for sustainable consumption. Consumer Policy Review, 16(4): 131-137.

Mader, B. Is Going Green Too Expensive for Most People? Sep 1, 2008 http://contractormag.com/columns/editorial/going_green_expensive/

Manderson, A.K. (2006). A Systems Based Framework to Examine the Multi-contextual Application of the Sustainability Concept. Environment, Development and Sustainability, 8(1): 85-97. 
Mantzoukas, S. (2004) Issues of Representation within Qualitative Inquiry.

Qualitative Health Research, 14, (7): 994-1007.

Marrewijik, M.V., \& Were, M. (2003). Multiple Levels of Corporate Sustainability. Journal of Business Ethics, 44: 107-119.

McCarthy, S. (2007). Sustain or become obsolete. Supply Management, 12(13): 34-35.

McCrindle Research (2007). Socially conscious or selfish and materialistic? Retrieved $22^{\text {nd }}$ October from http://www.mccrindle.com.au.

Miles, M. B., \& Huberman, A. M. (1994). An Expanded Sourcebook: Qualitative Data Analysis (2nd ed.), NY: Sage Publications International.

Mitchell, S. (1998). American generations: Who they are, how they live, what they think (2nd ed.), Ithaca, NY: New Strategist.

Morton, L.P. (2003). Targeting CEOs. Public Relations Quarterly, 48(1): 43-44.

Mujtaba, B., \& Jue, A.L. (2005). Deceptive and Subliminal Advertising in Corporate America: Value Adder or Value Destroyer? Journal of Applied Management and Entrepreneurship. (online) (31 Jan, 2007) Retrieved: May 25, 2008, from http://findarticles.com/p/articles/mi_qa5383/is_200501/ai_n21364362/pg_16.

Neumann, L.W. (2003). Social Research Methods - Qualitative and Quantitative Approaches. USA: Pearson Education, Inc.

Norum, P. S. (2003). Examination of generational differences in household apparel expenditures. Family and Consumer Sciences Research Journal, 32(1): 52-75. 
O'Guinn, T.C., \& Shrum, L.J. (1997). The Role of Television in the Construction of Consumer Reality. Journal of Consumer Research, 23(4): 278-294.

O'Shaugnessy, J., \& O'Shaugnessy, N.J. (2002). Marketing, the consumer society and hedonism. European Journal of Marketing, 36(5/6): 524-547.

Packard, V. (1960). The Waste Makers. Penguin: Harmondsworth in Robins, N. (1999) Making sustainability bite: transforming global consumption patterns. The Journal of Sustainable Product Design (online)(27 October 2007) Retrieved: March 23, 2008, from http://www.bo.cnr.it/www-sciresp/OLD/Bacheca_OLD/pdf00000.pdf\#page=7.

Paul, P. (2001). Getting Inside Gen Y. American Demographics, 23(9):42-49.

Placet, M., Anderson, R., \& Fowler, K.M. (2005). Strategies for Sustainability. Research Technology, 48(5): 32-41.

Rees, W. E. (1992). Ecological footprints and appropriated carrying capacity: What urban economics leaves out. Environment and Urbanisation. 4(2): 121-131. Retrieved: 23 march 2008 from http://www.footprintnetwork.org/en/index.php/GFN/page/frequently_asked_questions/).

Robins, N. (1999). Making sustainability bite: Transforming global consumption patterns. The Journal of Sustainable Product Design. (online)(4 December 2007) Retrieved: March 23, 2008, from http://www.bo.cnr.it/www-sciresp/OLD/Bacheca_OLD/pdf00000.pdf\#page=7.

Robins, N., \& Roberts, S. (1998). Consumption in a Sustainable World: Report of the Workshop held in Kabelvåg, June 2-4 1998, Oslo: Norwegian Ministry of Environment.

Sanne, C. (2002). Willing Consumers - or locked in? Policies for a sustainable consumption. Ecological Economics, 42(1/2): 273-287. 
Schewe, C.D., \& Meredith, G. (2004). Segmenting global markets by generational cohorts: Determining motivations by age. Journal of Consumer Behavior, 4(1): 51-63.

Schmuk, P., Kasser, T., \& Ryan, M. (2000). Intrinsic and Extrinsic Goals: Their Structure and Relationship to Well-Being in German and U.S. College Students. Social Indicators Research, 50(2): 225-241.

Shaw, D., Newholm, T., \& Dickinson R. (2006). Consumption as voting: An exploration of consumer empowerment. European Journal of Marketing. Bradford, 40(9/10): 1049-1067.

Sheahan, P. (2005). Generation Y: Thriving and Surviving with Generation Y at Work, Australia: Hardie Grant Books.

Smola, K.W., \& Sutton, C.D. (2002). Generational differences: revisiting generational work values for the new millennium. Journal of Organizational Behavior, 23, 363-382.

Strauss, W., \& Howe, N. (1991). Generations: The history of America's future, 1584 to 2069, New York: William Morrow.

Sullivan, P., \& Heitmeyer, J. (2008). Looking at Gen Y shopping preferences and intentions: exploring the role of experience and apparel involvement. International Journal of Consumer Studies, 32: 285-295.

Tanner, C., \& Kast, S.W. (2003). Promoting sustainable consumption: Determinants of green purchases by Swiss consumers. Psychology \& Marketing. 20, (10), p.883-902

Twitchell, J.B. (2002). Living it up: Our love affair with luxury. Columbia: University Press.

von Hippel, E. (1986). Lead Users: A source of novel product concepts. Management Science, 32, (7):791-805. 
Wackernagel, M., \& Rees, W.E. (1996). Our Ecological Footprint: Reducing Human Impact on the Earth. New Society Press.

Wellner, A.S. (2000). Generational divide. American demographics, 22(10): 52-58.

Wirtenberg, J., Lipsky, D., Abrams, L., Conway, M., \& Slepian, J. (2007). Empowerment, waste and new consumption communities. Organization Development Journal, 25(2): 11-21.

Wright, N.D., \& Larsen, V. (1993). Materialism and life satisfaction: A meta-analysis. Journal of Consumer Satisfaction, Dissatisfaction, and Complaining Behavior, 6: 158-165.

Zinkhan, G.M. (1994). Advertising, materialism and quality of life. Journal of Advertising, 23(2): $1-4$.

Zinkhan, G.M., \& Prenshaw, P.J. (1994). Good life images and brand name associations. Advances in Consumer Research, 21: 496-500. 


\begin{tabular}{|c|c|c|c|}
\hline \multicolumn{3}{|l|}{ Improvement Issues for the next 25 years } & \multirow{2}{*}{$\begin{array}{l}\text { What is sustainability } \\
\text { The young consumer perspective }\end{array}$} \\
\hline Very Frequently mentioned & Frequently mentioned & Less Frequently mentioned & \\
\hline $\begin{array}{l}\text { Political agendas need to focus on } \\
\text { sustainability and current } \\
\text { sustainable business practices } \\
\text { - Shifts in consumers attitudes and } \\
\text { values towards sustainability need } \\
\text { to be addressed using social change } \\
\text { campaigns } \\
\text { - } \quad \text { Education of individuals }\end{array}$ & $\begin{array}{l}\text { - Increase CSR, regulations and } \\
\text { compliance, } \\
\text { reemergence of the village } \\
\text { philosophy, Increased community } \\
\text { and social integration and physical } \\
\text { social interaction around } \\
\text { sustainability projects } \\
\text { Next generation is the most } \\
\text { important issue (Gen Z), beyond } \\
\text { educating, real life experiences } \\
\text { imperative } \\
\text { - Social issues: Health care, aged } \\
\text { care, greenhouse and climate, war, } \\
\text { religion } \\
\text { Sustainability addressed as a } \\
\text { global issue } \\
\text { Growth of less developed } \\
\text { countries } \\
\text { Work life balance, look to } \\
\text { education courses where there } \\
\text { future and jobs, } \\
\text { health and obesity strategies } \\
\text { Focus on socially moral issues to } \\
\text { direct consumers based on their } \\
\text { perceptions } \\
\text { Ethnocentric views towards } \\
\text { sustainable practices - } \\
\text { collaborative focus needed for } \\
\text { global acceptance } \\
\text { Developing and delivering a clear } \\
\text { definition of sustainability to } \\
\text { enforce change - without } \\
\text { understanding, change is minimal } \\
\text { Manage Societal degeneration } \\
\text { created by Gen tech - less } \\
\text { communication of face to face } \\
\text { contact } \\
\text { Planning the present, investing and } \\
\text { developing new technologies, } \\
\text { processes and practices } \\
\text { Raise social awareness }\end{array}$ & $\begin{array}{l}\text { Increase sense of community belonging, } \\
\text { to reduce transport costs focus on the } \\
\text { creation of community hubs physically } \\
\text { and through technology } \\
\text { Terrorism } \\
\text { - } \quad \text { Balance of investment to cover } \\
\text { sustainability issues } \\
\text { Increase incentives for implementing } \\
\text { CSR and developing community increase } \\
\text { incentives to business to position in } \\
\text { suburbs' and communities to create } \\
\text { villages. } \\
\text { Positive reinforcement for reducing travel } \\
\text { and emissions by operating small stores } \\
\text { locally. } \\
\text { Creations of new core values from family } \\
\text { and maintain and educate traditional-shift } \\
\text { and include a sustainable life } \\
\text { Ensuring countries using a vast amount } \\
\text { of natural resources of the world or are } \\
\text { major contaminants become responsible } \\
\text { for such actions } \\
\text { Larger developed countries to offer aid to } \\
\text { countries with large resource shortages } \\
\text { Domino effect - address all segments of } \\
\text { the market to address the sustainability } \\
\text { issue }\end{array}$ & 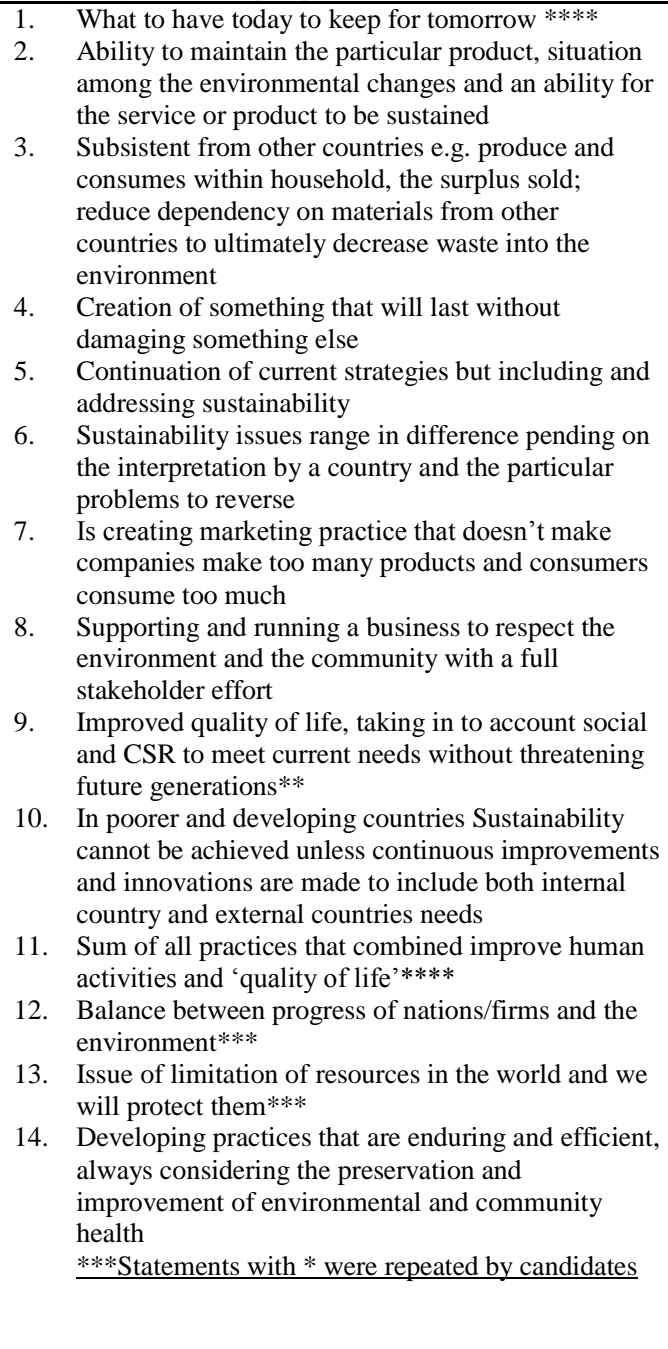 \\
\hline
\end{tabular}




\begin{tabular}{|c|c|c|}
\hline Very Frequently & Frequently & Less Frequently \\
\hline \multicolumn{3}{|l|}{ Economic } \\
\hline $\begin{array}{l}\text { Unevenly distributed } \\
\text { world's population } \\
\text { Social and educational } \\
\text { gaps on a global level } \\
\text { Income disparity }\end{array}$ & $\begin{array}{ll}\text { - } & \text { Interest rates balanced } \\
\text { - } & \text { Inflation Rates } \\
\text { The need for companies to be established under the belief of } \\
\text { - } \quad \begin{array}{l}\text { Profit motinable investment practices } \\
\text { sustainable practice }\end{array} \\
\text { - The need to consider the economic status of emerging countries } \\
\text { - } \quad \text { Production constraints due to scarcity of resources } \\
\quad \text { developing countries }\end{array}$ & $\begin{array}{l}\text { - } \quad \text { Managing growth crash or bust } \\
\text { - } \quad \text { Mew industry management and market entry } \\
\text { - } \quad \text { resources } \\
\text { - } \quad \text { Aim of less developed countries to aspire to 'Western Style' economies - e.g. Thai } \\
\text { - } \quad \text { Manome driven by other nationalities rather than independent ideologies } \\
\text { - } \quad \text { Changes in investor behavior, cost factors, emerging economic forces } \\
\text { - Investment to restitute and restore usage or damages } \\
\text { - Introducing loan support and strict protocols for money lending }\end{array}$ \\
\hline \multicolumn{3}{|c|}{ Social people and community } \\
\hline Very Frequently & Frequently & Less Frequently \\
\hline $\begin{array}{l}\text { Housing, investment, } \\
\text { interest rates, hourly pay } \\
\text { rates } \\
\text { Care for the community } \\
\text { growing, ageing } \\
\text { Excessive, dangerous } \\
\text { consumption }\end{array}$ & $\begin{array}{l}\text { - } \quad \text { Materialism and excessive consumption } \\
\text { - } \quad \text { Neglect from government in less developed countries } \\
\text { - } \quad \text { peers } \\
\text { - Share common values and respect and take into consideration } \\
\text { people, family and community } \\
\text { Travel time to work and transport infrastructure to make travel } \\
\text { more efficient } \\
\text { - } \quad \text { Educational courses for the real world i.e. guaranteed employment } \\
\text { - Conscious awareness increased of sustainable issues }\end{array}$ & 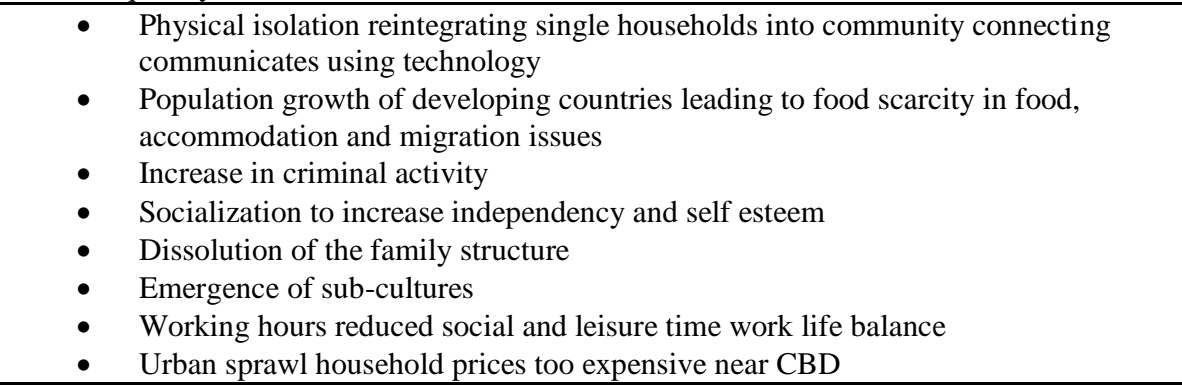 \\
\hline \multicolumn{3}{|l|}{ Technological } \\
\hline Very Frequently & Frequently & Less Frequently \\
\hline $\begin{array}{l}\text { Privacy Invasion - } \\
\text { security issues of the } \\
\text { internet } \\
\text { Convenience, minimal } \\
\text { time and economic costs, } \\
\text { efficiency of content and } \\
\text { practice } \\
\text { Adaptability towards } \\
\text { technology }\end{array}$ & $\begin{array}{ll}\text { - } & \text { Making technology more social and intimate-.webcam and audio } \\
\text { - } & \text { Continually advancing technology speed and capacity } \\
\text { - } & \text { Luxury product, status symbol representative of social class } \\
\text { - } & \text { E-learning rather than E-entertainment } \\
\text { - } & \text { Increase in online communications resulting in lack of deep } \\
\text { - } & \text { Internet addiction } \\
\text { - } & \text { Cyber isolation } \\
\text { - } & \text { Social networking }\end{array}$ & 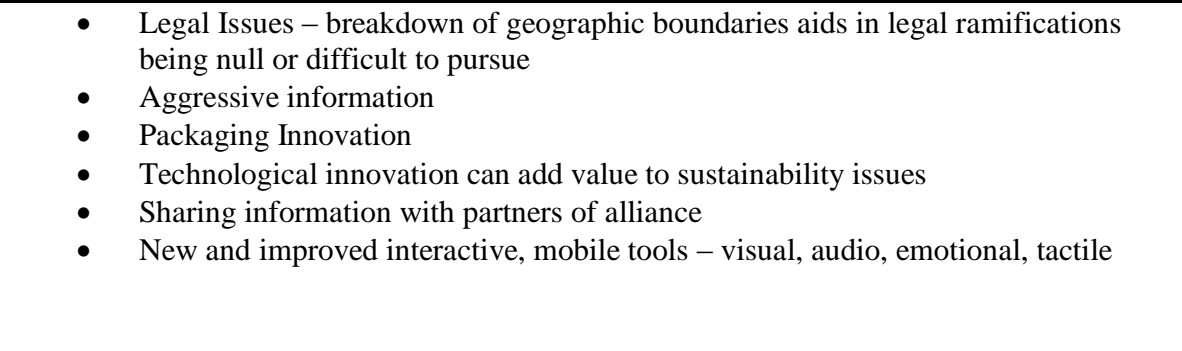 \\
\hline \multicolumn{3}{|c|}{ Environmental and ecological } \\
\hline Very Frequently & Frequently & Less Frequently \\
\hline
\end{tabular}




\begin{tabular}{|c|c|c|}
\hline Very Frequently & Frequently & Less Frequently \\
\hline $\begin{array}{l}\text { Individuals taking more } \\
\text { responsibility for impact } \\
\text { on environment } \\
\text { Recycle, Fuel efficiency, } \\
\text { green, renewable energy, } \\
\text { power, Bio-fuel }\end{array}$ & $\begin{array}{l}\text { - } \quad \text { Corporate Social Responsibility } \\
\text { - } \quad \text { Global warming and destruction of forests } \\
\text { - New initiatives and programs for developments plus incentives to } \\
\text { - } \quad \text { Procue practices that deplete natural resources } \\
\end{array}$ & $\begin{array}{l}\text { - } \quad \text { Changes in weather patterns will directly affects consumer's habits and routines } \\
\text { - } \quad \text { Eco Tourism, green marketing } \\
\text { - } \quad \text { Preservation of natural resources however always prioritizing human/social capital } \\
\text { - Tax on emissions }\end{array}$ \\
\hline \multicolumn{3}{|c|}{ General business and marketing practice } \\
\hline Very Frequently & Frequently & Less Frequently \\
\hline $\begin{array}{l}\text { Energy efficient business } \\
\text { increasingly important } \\
\text { New marketing practices } \\
\text { for new generations } \\
\text { Incorporation and } \\
\text { implementation of } \\
\text { appropriate policies and } \\
\text { regulations }\end{array}$ & $\begin{array}{l}\text { - Traditional business channels replaced by internet and interactive } \\
\text { channels of distribution } \\
\text { Application of technological innovations as a pathway to business } \\
\text { to customers } \\
\text { - Investing responsibly, reducing packaging and waste, } \\
\text { employment, sensible management, human resource systems } \\
\text { - Agricultural sector expected to grow in face of food reduction } \\
\text { from global warming } \\
\text { - Societal marketing practices essential to enhance changes in } \\
\text { consumption patterns and attitudes towards the respect of the } \\
\text { planet and community care. }\end{array}$ & 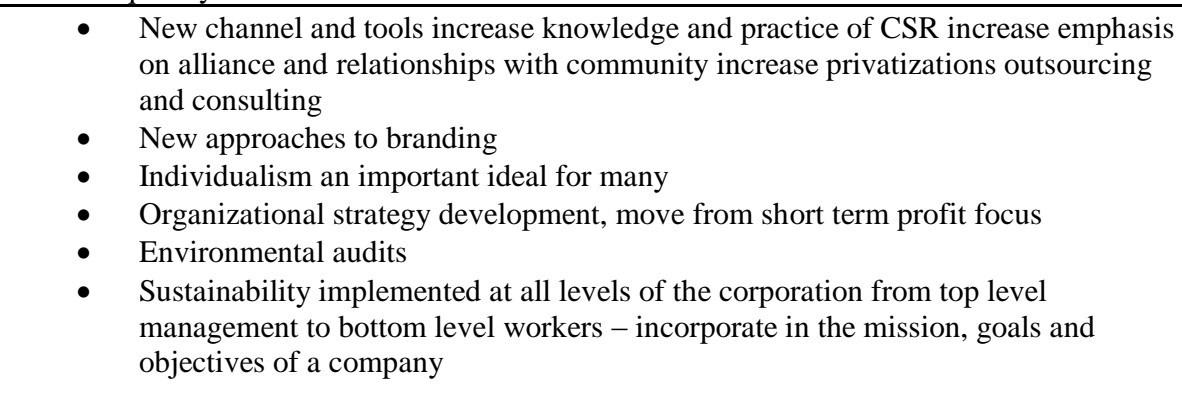 \\
\hline
\end{tabular}


Table Three: Modified Ecological Footprint Questionnaires Results

\begin{tabular}{|c|c|c|c|}
\hline "TABLE THREE: FOOTPRINT RESULTS & $\begin{array}{l}\text { Never chooses the friendly } \\
\text { option and/or adopts } \\
\text { unfriendly practices }\end{array}$ & $\begin{array}{l}\text { Practices positive } \\
\text { behavior less that } \\
\text { once a month } \\
\end{array}$ & $\begin{array}{l}\text { No } \\
\text { comment }\end{array}$ \\
\hline Bio mass factors: Eats processed meats, cheese and diary & All (60) & 0 & 0 \\
\hline $\begin{array}{l}\text { Bio mass factors: Do you consume packaged food regularly daily? Weekly? } \\
\text { Monthly? }\end{array}$ & 53 & 2 & 5 \\
\hline $\begin{array}{l}\text { Bio mass factors: Recycling of waste in particular separating rubbish, reusing } \\
\text { materials for other purposes such as building, clothing and paper. }\end{array}$ & 41 & 3 & 16 \\
\hline $\begin{array}{l}\text { Technology: Do you own more than two pieces of technology and replace them } \\
\text { regularly }\end{array}$ & 60 & 0 & 0 \\
\hline Building: What is the size of your home and how many people share & $\begin{array}{l}37 \text { large homes not filled to } \\
\text { capacity }\end{array}$ & $\begin{array}{l}10 \text { homes with more } \\
\text { that } 3+\& 11 \text { flat/unit } \\
\text { with co habitants }\end{array}$ & 2 \\
\hline Waste: How much waste do you generate 1 or more garbage bags, bins etc & 40 (4-6 bags per week) & $\begin{array}{l}12(1-2 \text { bags per } \\
\text { week })\end{array}$ & 8 \\
\hline Waste: Do you repair and renovate goods & 57 & 0 & 3 \\
\hline Carbon: Do you have more than one fridge & 52 & 6 & 2 \\
\hline $\begin{array}{l}\text { Carbon saving: Do you use any forms of renewable energy? Such as Rechargeable } \\
\text { batteries? }\end{array}$ & 41 & 8 recharge batteries & 11 \\
\hline $\begin{array}{l}\text { Water conservation: Do you use water saving devices? Own a water tank and } \\
\text { conserve water? }\end{array}$ & 46 & 3 tanks & 11 \\
\hline Carbon: Do you fly on a plane annually, monthly, weekly & 57 & 0 & 3 \\
\hline Carbon: Do you drive a car more than 100 kilometres a week & All total 60 & 0 & 0 \\
\hline Carbon: How many people travel in your car? & Mostly alone 52 people & $\begin{array}{l}3 \text { commute and car } \\
\text { pool }\end{array}$ & 5 \\
\hline Carbon saving: Do you walk or cycle to work, shops for leisure & $\begin{array}{l}\text { Most drove or took public } \\
\text { transport }(56)\end{array}$ & 1 rode bike & 3 \\
\hline Bio mass reduction: Do you grow your own food fruit or vegetables & All did not grow produce & 0 & 0 \\
\hline $\begin{array}{l}\text { Water conservation and Bio mass reduction: Do you mulch your garden and } \\
\text { recycle garden waste }\end{array}$ & 57 & 0 & 3 \\
\hline $\begin{array}{l}\text { Carbon saving: Do you use any renewable energy sources in your home or } \\
\text { workplace }\end{array}$ & $\begin{array}{l}8 \text { considered rechargeable } \\
\text { batteries as renewable, no }\end{array}$ & $* * 8$ & 0 \\
\hline
\end{tabular}




\begin{tabular}{|c|c|c|c|}
\hline & solar & & \\
\hline Do you use any renewable energy with your transport & 59 no & 1 bike rider & 0 \\
\hline Carbon: Do you use air-conditioning or heating & $\begin{array}{l}\text { All use air-conditioning in } \\
\text { summer }\end{array}$ & 0 & 0 \\
\hline $\begin{array}{l}\text { Renewable recycling: Do you lend and borrow and share items amongst friends } \\
\text { and family that you do not need or use often }\end{array}$ & $\begin{array}{l}\text { Most borrowed books from a } \\
\text { library, No other borrowing }\end{array}$ & 0 & 0 \\
\hline Do you manage your debt and consumption? & $\begin{array}{l}\text { Most spent what they earn and } \\
\text { saved little and owned several } \\
\text { credit cards } 47\end{array}$ & $\begin{array}{l}2 \text { saved and non } \\
\text { credit }\end{array}$ & 11 \\
\hline $\begin{array}{l}\text { Do you believe you make more effort to protect the environment that you did 1-5 } \\
\text { years ago }\end{array}$ & 12 (worse) & 30 (yes) & $\begin{array}{l}18 \text { (no } \\
\text { change) }\end{array}$ \\
\hline
\end{tabular}


